German Cinema

in the Age of Neoliberalism 



\section{German Cinema in the Age of Neoliberalism}

Hester Baer 
The publication of this book is made possible by a grant from the University of Maryland, College Park.

Cover illustration: Patrick Bauchau \& Crew in The State of Things (Portugal, USA, Germany 1981/82) by Wim Wenders (C) Wim Wenders Stiftung 2015

Cover design: Kok Korpershoek

Lay-out: Crius Group, Hulshout

$\begin{array}{ll}\text { ISBN } & 978 \text { 94 } 63727334 \\ \text { e-ISBN } & 978 \text { 90 } 48551958 \\ \text { DOI } & 10.5117 / 9789463727334 \\ \text { NUR } & 670\end{array}$

\section{(c) $(1) \Theta$}

Creative Commons License CC BY NC ND (http://creativecommons.org/licenses/by-nc-nd/3.o)

(a) H. Baer / Amsterdam University Press B.V., Amsterdam 2021

Some rights reserved. Without limiting the rights under copyright reserved above, any part of this book may be reproduced, stored in or introduced into a retrieval system, or transmitted, in any form or by any means (electronic, mechanical, photocopying, recording or otherwise).

Every effort has been made to obtain permission to use all copyrighted illustrations reproduced in this book. Nonetheless, whosoever believes to have rights to this material is advised to contact the publisher. 